\title{
TEXTUAL SPACE OF THE MUSIC DISCOURSE: THEORY, PRACTICE
}

\author{
Piatnitska-Pozdnyakova I. S.
}

\section{INTRODUCTION}

The stated issue is represented by thorough interdisciplinary theoretical research, which allows us to speak about its relevance, which today remains open for reflection. However, one of the understudied aspects is the study of musical discourse as a text space. In this regard, the article deals with the issue of musical discourse which is deemed as a multidimensional text space; taking into account modern trends in the development of linguistics and musicology, the concept of "musical discourse" is analyzed. The article identifies the essential characteristics of musical discourse from the perspective of modern semiosis. The article analyzes the concept of "discourse" from the perspective of modern linguistics and musicology. It is emphasized that the term "discourse" has deep roots and a variable etymology that has changed over a long time and has had a vector of interpretation from "analytical actions" to "the mechanism of language actualization" in the communication system. The purpose of the article is to reveal the features of musical discourse as a complex text space with a diversity of its perception, which can take the form of a fixed event, in the context of which the musical culture of a certain historical and cultural period is represented.

Literature Review. Generally, the etymology of the term "discourse" has its roots in the Latin "discurrere" (to negotiate, to discuss), which in the context of medieval science was interpreted as "reflection", i.e., logically organized oral (or written) speech. In this sense, the semantics of the term "discourse" is similar to the concept of "text" as a unity of semantically connected integral sequence of signs. During the XVI-XVIII century the term "discourse" was used in this sense and was synonymous with scientific research, and analytical actions stood for discursive thinking, through which it was possible to attain knowledge of any phenomena. However, in the XVIII century, the concept of discourse acquires additional characteristics due to introspection as an integral part of the discursive analysis, which involves an appeal to the internal structures of the studied phenomenon.

In the XIX century, the forms of scientific discourse gradually changed along with the form of presentation of scientific results, and the concept itself began to function both in the field of exact (purposeful, logical scientific thinking) and humanitarian (free expression of thought, which may not be scientifically structured) sciences. However, the discourse retains its key 
feature of normativity, which implies the presence of formal and logical structures. However, at the beginning of the twentieth century the issue of discourse got a new vector of development, and the term "discourse" was widely used in the context of the human sciences, which was usually associated with the work "Language and discourse" by the Belgian linguist E. Buisans, where the binary opposition "language - speech" was expanded, and the term itself was conceived of as a mediator between language and the process of speech. In this context, discourse becomes a mechanism of language actualization in the communication system.

Presented in the D. Busse - V. Toibert's theory, the term "discourse" was conceived as a virtual corpus of texts that correspond to a specific topic (concept); linked by semantic links; have certain time-space boundaries, in the context of which they are discussed, and the scope of communication (types of texts); have implicit and explicit links, which are identified by analyzing the text or context, forming intertextual links) ${ }^{1}$. The theory of D. Busse - V. Teubert was analyzed By M. Jung, who based on it developed an approach to operations with linguistic texts, while the discourse itself was conceived as a set of a whole frame of statements related to the topic but not limited to the type of text. From M. Jung's point of view, texts are not always monothematic, so they can become elements of several discourses. In other words, the commonality of the topic is not always the criterion for selecting a discourse, so the discourse may contain statements on different topics.

Subsequently, M. Jung proposed a model that shows internal differentiation of discourse according to three criteria, namely: content, the scope of communication (the possibility of implementation in various spheres of communication), and types of texts (possibilities of implementation in different types of texts).

In general, theories of discourse in humanitarian thought arose under the influence of linguistic studies, in the context of which it was emphasized that the language analysis should take into account not only grammar but also the process of its functioning in society (speech interaction, etc.). As a result, various approaches emerged, including critical discourse analysis (T.A. van Dyck, N. Ferklow, R. Vodak), structural analysis of myths and the study of communication methods in different cultures (V. Labov, N. Ros), cognitive models of understanding coherent text and discourse (T.A. van Dyck, D. Kinch), and so on.

In the second half of the twentieth century, the discursive practice changed significantly, and discourse itself became one of the key categories of scientific analysis, the subject of special research in philosophical and sociohumanitarian disciplines, which led to the emergence of a whole range of

\footnotetext{
${ }^{1}$ Hoffmann L. Kommunikationsmittel Fachsprache: Eine Einführung. 3. Aufl. Berlin : Sammlung Akademie-Verlag Sprache 44, 1987. 307 s.
} 
interdisciplinary research. Since the $60 \mathrm{~s}$, the term "discourse" has acquired a categorical meaning and starts correlating with the concept of "text", which is facilitated by the development of semiotics as a specialized field of knowledge. In the $70 \mathrm{~s}$, the term "discourse" was specified, which was interpreted as a way of text actualization, where text and speech were considered aspects of discourse. At the same time, recognizing the primacy of the text to discourse, the dynamic form of the text's existence was studied, and various actions with language and speech fell into the field of research. Such approaches to discourse have contributed to the emergence of various tendencies, including sociolinguistics, semiotics, French discourse analysis, speech acts theory, and critical discourse analysis. At the same time, the aim was to integrate various concepts, which led to the emergence of interdisciplinary research, where the organization of the meaning of discourse was defined by the "theme" as a dynamic formation that unfolds in the context of the discursive practice.

\section{Theoretical scope of the term "discourse"}

In the $90 \mathrm{~s}$ and early $2000 \mathrm{~s}$, discourse theories were most intensively integrated into various fields of knowledge, forming interdisciplinary connections. In particular, such connections are observed between linguistics and psychology, linguistics and sociology, psychology and anthropology, which contributed to the emergence of a new branch - discursology and allowed to expand the semantic field of the term "discourse" from purely linguistic to philosophical, acquiring the status of an independent approach, in particular:

- from the standpoint of the linguistic approach, discourse is a structurally complete content-language formation, which can consist of several utterances or a complete text;

- from the standpoint of the functional approach, discourse is a way of language functioning in a social context;

- from the standpoint of a pragmatic approach, discourse is a sociocultural space;

- from the standpoint of the philosophical approach, discourse is a body of rules that have historical, cultural, and social characteristics.

Such a wide range of discourse research contributed to an extremely large variety of terms for the concept itself, which is thought of as a text, as a cognitive process, and as the implementation of the speech process in a specific communication situation, acquiring a socio-cultural aspect, and so on.

Besides, different theories arise in the context of these approaches. In particular, one of them is the pragmatic theory of Y. Habermas and K.O. Apel, in the context of which discourse was conceived as a kind of socially-oriented practice, forming a behavioral model. The other represents 
the theory of discourse analysis presented by the works of J. Baudrillard, J. Lacan, M. Pesce, and others, in the context of which the tradition of understanding discourse as a rhetorical formation was continued, which influenced the further development of discursive practice and contributed to the emergence of the theory of discursive formations of the French linguist and sociologist M. Foucault. In his theory, the term "discourse" was used to denote socio-historical systems of human knowledge and was conceived as an integral part of "discursive practice", as a set of various spheres of human knowledge, that are determined by a specific time-space continuum. From his point of view, the discourse has historically conditioned, so it is deemed not so much as a set of signs used to designate objects, phenomena, but as a socio-historical background, which correlates events with discourse ("the world of discourse"). In this context, discourse seeks to answer the question, not "what is said", but "why is this or that said?". This theory was further developed in the context Of M. Pesche's "automatic analysis of discourse" and J. Lacan's analytical theory of discourse, which influenced the development of the philosophical paradigm of discourse research in general.

Further development of verbal speech mechanisms led to the deepening of the semantics of the term "discourse", which was conceived as a process of speech (E. Benveniste), as a way to actualize the text in certain mental and pragmatic conditions in connection with extralinguistic factors (T. A. van Dyck), as a speech flow (G. Pocheptsov), as a complex syntactic whole (V. Borbotko), as a certain type of mentality (N. Arutyunova), as a voiced consciousness (A. Revzina), as a text that occurs in the process of speech (V. Konetska), as a thought-speech practice (V. Milovidov), and so on. As we can see, in the context of linguistics, considerable knowledge has been accumulated in the study of discourse, which is thought of both as a processual phenomenon and as a process of speech, in the context of which the text or its perception is born, etc. This understanding of discourse is consonant with the French semiotic tradition, according to which discourse is thought of as a mental formation that arises in the imagination and reflects the main and additional meanings in the process of its perception as speech "immersed in life".

The understanding of discourse as a thought-speech activity, which is both a process and a result, is also common in modern linguistics, where discourse is understood as a separate text that is in a certain semantic connection with another, and a particular case of a text such as a speech or article, or a sum of texts that reflect other texts that are characterized by integrity.

The new perspective of understanding discourse as a text related to a possible dimension is due to the appearance of M. Heidegger's metaphor 
"language is the house of being". Subsequently, the correlation of language with "possible dimensions" led to the discourse's obtaining a new social aspect, that is, the existence of discourse is possible primarily in the texts "... which have special grammar, a special lexicon, special rules of word usage and syntax, special semantics"3. This position was expressed by $\mathrm{Yu}$. Stepanov, according to him, each discourse is "one of the possible worlds", the actions and objects of which are realized according to the logic of this world. In other words, discourse is a mental model, a kind of knowledge that is stored in memory, the structure of which corresponds to the structure of the presented situation, on which depends its interpretation ${ }^{4}$. Consistent with this understanding is the vision of discourse as a reflection of the mentality, culture (national or individual), which connects it with the concept of genre and style of speech ${ }^{5}$.

In general, in various explanatory dictionaries the definition of the term "discourse", despite minor differences in wording, highlights such main characteristics as communicativeness, dialogical nature (openness, interactivity), dynamism, pragmatism (audience orientation), macro situational nature, illocution (setting and solving problems is carried out in the process of speech), time limitation, social orientation and language functionality, psychologically-oriented space (i.e. enabling both verbal and non-verbal communication, limited by time and human factors) and the like.

From another point of view, discourse is thought of as a complex communicative form of language, which reflects the mentality of an ethnic group, or a set of knowledge in a particular field of culture, which is fixed by sign systems. At the same time, the communicative form is understood as oral speech, written and non-verbal text of the author, which springs in his imagination. From this point of view, the text is regarded as a discourse and discourse as a special form of language functioning ${ }^{6}$. I.e., texts can also contain a particular discourse that can be attributed to a specific social or professional group as an alternative world, which actualizes vocabulary and grammar in various types of discourse. I. e., discourse permits to reproduce the lexical and syntactic features of the language of a particular person, their worldview, and it is a reflection of both social practices and socio-cultural knowledge in general. Discourse is not seen as mental, but pragmatic and communicative activity ${ }^{7}$, in the context of which the language is focused on

\footnotetext{
2 Миронова Н. Оценочный дискурс: проблемы семантического анализа. Известия $A H$ Сер. Литература и язык. 1977. Т. 56. № 4. С. 52-59.

${ }_{3}$ Степанов Ю. Альтернативный мир, дискурс, факт и принцип причинности. Язык и наука конияа 20 века: сборник статей. Москва : РГУ, 1995. С. 45.

4 Джонсон-Лэрд Ф. Процедурная семантика и психология значения. Новое в зарубежной лингвистике. Вып. 23 Когнитивные аспекты языка. Москва : Прогресс, 1988. С. 234-255.

${ }_{5}^{5}$ Будагов Р. Введение в науку о языке. Москва : Просвещение, 1965. 492 с.

${ }^{6}$ Kubryakova Elena. Types of space, text and discourse. Space and time: scientific materials. conf. Moscow : Moscow State University, 1997: 19 c.

Karasik Vladimir. About the categories of discourse. Linguistic personality: sociolinguistic and emotional aspects: Sat. scientific tr. Volgograd; Saratov : Peremen, 1998: C. 185-197.
} 
discourse, and the texts are the result of speech activity, the generalization of which occurs at the level of language system.

In most works, the definition of "discourse" is given using the term "text". However, there are different approaches to solving the "discourse-text" dichotomy: from complete identification to differentiating concepts according to different parameters, or including "text "in a broader category of "discourse". This diversity arose as a result of the terminological inconsistency of the term "discourse analysis", which received the equivalent of the concept "text linguistics" in the scientific German school, which denoted the discipline that deals with the study of the text. In this sense, discourse is understood as "speech immersed in life", which reflects its real nature of the speech process in contrast to ideal models. In other words, discourse is thought of as "text in action", which allows us to establish a relationship between the "discoursetext" dichotomy. This indicates that the term "discourse" is multidimensional and multifunctional, and is still polysemantic and is the object of research in various disciplines.

In general, the distinction between the categories of "text" and "discourse" was introduced by T.A. van Dyck. In general, Dyck's research presents a socio-cognitive discourse analysis that reveals the practice of social reality with its ideological settings (problems of discrimination, racism, and the like). A detailed analysis of discursive practices of social reality allowed the scientist to understand how their sociocognitive foundations are formed, which are based on both individual and social representations in their most diverse forms. In the works "Strategy for understanding a coherent text", written by T.A. van Dyck in collaboration with V. Kinch, the term "discourse" is used both in the meaning of "text" focused on a specific meaning and in the meaning of "speech". This understanding further led to the identification of discourse pragmatics and the development of a cognitive model of text processing. It should be noted that the classification of Dyck's discourse theories is based on the disciplinary-genetic approach outlined by the scientist in the introductory article to the first volume of the four-volume "Handbook of discourse analysis", emphasizing that the involvement of various disciplines in the study of discourse leads to the formation of diverse areas of discourse analysis in the Humanities and Social Sciences, considered by him as the result of integrative interdisciplinary processes. This expansion of the subject field of discourse indicated the introduction of new methodological approaches to the theory of discourse. However, if the early approaches to discourse analysis, from the point of view of Dyck, were associated with a structural approach, where the subject of study was myths and rituals, then later discourse analysis was enriched by semiotic methods of research of various texts, the emergence of new branches of knowledge (cognitive psychology). 
In the late $70 \mathrm{~s}$ of the twentieth century, there was a differentiation of concepts, where "text" was understood as "abstract, formal construction" and discourse as "various types of its actualization, considered from the point of view of mental processes and in connection with extralinguistic factors".

In other words, the text was conceived as a basic component of discourse, which is a verbal expression of social practice in its various communicative spheres, as an ordered and systematic use of language, which is backed by a specific culture conditioned mentality. In most works, the definition of discourse is given using the term "text", but there are different approaches to resolving the "discourse - text" dichotomy: from complete identification to delineation of concepts according to different parameters, or including "text" in a broader category of "discourse". This diversity arose as a result of the terminological inconsistency of the term "discourse analysis", which became the equivalent of "text linguistics" in the scientific German school and denoted the discipline that deals with the study of text. Text linguistics played a significant role in this terminological ambiguity, in the context of which the concept of "text" and "discourse" were used interchangeably, but the difference between them was not considered fundamental. This indicates that the term "discourse" is multidimensional and multifunctional, which has not yet got rid of multisemantics and has become the object of research in various disciplines.

However, over time, conditions for distinguishing these two concepts were formed, where the "text" began to be understood as an complete verbal product, and an attempt was made to identify categorical features of discourse, among which: the multiplicity of structure, which determines its sign nature; semantic unity; the combination of social with introspective; the ability to form different meanings; extralinguistic orientation. Despite a fairly wide range of studies of discourse, they can be grouped into two sets:

- discourse as a cognitively conditioned communicative event that is recorded in written texts. From such positions, discourse is a unit of operational analysis that has a purely functional range. At the same time, discursive analysis provides for the identification of components of the communicative process, reflected in its intra-textual organization, and the nature of the influence of extralinguistic factors (social, cultural, etc.) on the formation of language patterns;

- discourse as a set of thematically correlated texts that function within a single communicative sphere or "discursive formation" (in Fouco's terminology), the content dimension of which is revealed through intertextual connections. In this sense, discourse as a pragmatically directed temporalspatial continuum can have an oral or written form, verbal and nonverbal components, represent a separate historical period, a social community, or an entire culture. At the same time, discursive analysis involves identifying the common features that unite various texts in a single discursive space and 
analyzing the strategies that are implemented in them. In other words, the emphasis is on the conventional nature of communication, which is associated with the pragmatic conditions for generating and perceiving different types of texts.

Despite the fact that these are various approaches to the definition of discourse, they are not fundamentally different, since they emphasize different sides of the same phenomenon and determine such characteristics as: communication; dialogic character; dynamism; pragmatism; macrosituational nature; illocutivity (the setting and solution of problems is carried out in the process of speech); time limitation; social orientation and speech functionality; psychologically oriented space (i.e. the inclusion of both verbal and nonverbal communication, limited by the temporal-spatial and human factors, which allows to identify the semantic unity of various texts), and so on.

One interesting approach to discourse is understanding it as an integral set of functionally organized, contextualized units of language use, which was developed in the works of many researchers, in particular E. Benveniste, A. Leontiev, M. Bakhtin, Yu. Stepanov, A. Luria, Y. Brown, A. Levinson, S. Wilson, and many others. From the point of view of structural linguistics, the understanding of discourse implies semantic connections between sentences. In most definitions, discourse is considered a special language formation, which correlates with a certain branch of public practice and the process of communication. Such a rather diverse range of understanding of the concept of "discourse" indicates its multi-aspectuality and multifunctionality, where the term itself becomes polysemantic and becomes the object of research in various disciplines.

Regardless of the research direction, most scientists recognize text as the core of discourse as a complex synergetic product, the birth process of which occurs at the level of consciousness of the individual and appeals to emotional experience, genetic and cultural information and socio-cultural knowledge, providing an adequate response to the challenges of the surrounding reality ${ }^{8}$. In this sense, discourse acts as a mediator of socio-cultural communication and is characterized by specific features (thematic, lexical, syntactic, etc.) that "actualize its meaning, intentions and functions".

Despite such a variety of different approaches to the study of discourse, there is still no clear definition of what instrumental level it belongs to. Quite an extensive number of definitions of discourse allows us to interpret it as an approach, as a form of text analysis, as a set of different analysis techniques, as a language studying tool (its structure, functions and ways of application), and so on.

\footnotetext{
8 Клименюк А. Знание, познание, когниция: [монография]. Тернополь : Підручники i посібники, 2010.

9 Потапчук М. Песенный дискурс как коммуникативный процесс. Вестник Челябинского государственного ун-та. Филология; Искусствоведение 2 (293) (2013): 140-143.
} 
Such a diverse terminological dimension of discourse testifies to the existence of both broad and narrow understanding of it. In particular, discourse in a narrow sense is understood as a dynamic process of generating and perceiving a text that has a socio-cultural and pragmatic orientation. In a broad sense, this process includes the process of speech and the text itself that are specific concepts in relation to the generic "discourse" that unites them.

\section{Textual space of the music discourse: practical extinction}

In the twentieth century, extrapolation of the concept of "discourse" in the field of musical art allowed to reach a new level of understanding the sociocultural space with its innovative, complex musical text and a variety of forms (performing, analytical interpretations, etc.). Musical discourse is thought of as a relatively fixed event, which has a clear vector of presentation of musical culture of a certain time, where musical texts take the form of resonant events that allow to expand the boundaries of the socio-cultural situation and contribute to the renewal of musical traditions. The extremely complex sociocultural period of the 20 th century music art development, with its definition of significant values and concepts that were encrusted in a somewhat unfavorable context of the ideological coordinate system, was able to focus attention on the need to root the idea of self-worth and uniqueness of musical culture into the musical space. The emphasis on the most important semantic accents of the musical culture of that time, the structuring of the communication space around various musical events allowed not only to preserve the composer's own achievements, but also to encrust new development trends in its context.

Introduced into theoretical musicology, the term "musical discourse" denoted complex processes in the development of musical culture of the twentieth century with its extremely complex genre and style potential and the dynamics of socio-cultural development. In this sense, musical discourse was conceived as a complex semantic space, a kind of macrostructure, and had several dimensions, including:

- institutional, which reveals the relationship between the individual and various institutions and is represented by a wide variety of forms (presentations, representations, interpretations) and various levels of abstraction (written, oral, visual, etc.);

- contextual, revealing variants of the socio-cultural situation in which the discourse is implemented;

- mental, revealing the values and motivations of artist's creativity;

Any discourse can be "...discovered, described and understood only in context" ${ }^{\prime 10}$, which will allow decoding its semantic dimensions. This is an important thesis, because in the context of musical discourse as a socially

${ }^{10}$ Водак Р. Язык. Дискурс. Политика / пер. с англ. и нем. Волгоград : Перемена: 1997.76 с. 
directed interaction, text structures acquire multiple meanings, and their understanding takes place on the socio-cultural, historical, stylistic, grammatical (syntactics), semantic (semantics), motivational (pragmatics) levels that together determine the strategy of its representation.

In general, the take on music as a discourse is not new in theoretical musicology and has received its interpretation in the context of the works of both domestic and foreign researchers. The sociology of music contributed the most to the problem of understanding musical discourse, which focused on the study of the social aspect of music, however, the concept of "musical speech" and "musical text" was left out of attention. At the same time, most scientists thought of discourse as a multidimensional "text space" (according to Yu. Lotman), in which the mental model of the artist's personality is represented, that manifests itself at the level of interpretations, semantic reconstructions open to the polylogue, and so on. However, in theoretical musicology, the term "music discourse" has not received a methodological justification, as evidenced by the openness of its definition field, the uncertainty of types and criteria for analysis, genre-style varieties, modes, and so on.

However, some analytical works emphasize the functioning of artistic practices of composers in the discursive space of musical culture. In particular, in the works of O. Beregova, the concept "discourse" is thought of as a "complex communicative phenomenon", and "music discourse" is represented as a "communicative event", as "...the process of deployment and interpretation of a musical work as a stream of musical-speech behavior, "buried" in the situation of musical communication".

From such positions, the goal of musical discourse is "...the expression and transmission of emotionally organized artistic information by means of sound matter; the method of its implementation is a creative dialogue between all participants of musical communication, which is carried out behind several qualitatively different lines of communication" $"$. The problems of musical discourse were also deemed in the context of intertextuality, as one of the forms of its manifestation. At the same time, in the broad sense, intertextuality was deemed as the existence of constant and dynamic components in the musical text, and in narrow sense as the presence of "another's word" (in the terminology of M. Bakhtin) in the form of various "shapes of intertext". It is M. Bakhtin's ideas about "another's word" that occur during interaction with other texts "...forming a "dialogue""13, and that had important influence on the formation of intertextuality, as the presence of previous literary texts elements in the new text.

11 Берегова О. Сучасні теорії дискурсу і рефлексії в розробці теорії музичної комунікації. Актуальні проблеми мистецької практики і мистецтвознавчої науки. Мистецькі обрії 2 (11). (2009): 185-191.

12 Ibidem.

13 Бахтин М. Проблемы содержания, материала и формы в словесном творчестве. Bonpocbl литературы и эстетики. Москва : Худож. лит., 1975.: 35. 
In theoretical musicology, the understanding of intertextuality as a huge citation fund was stated in the works of B. Gasparov and received a fairly wide range of interpretations from "the quotation to the "structure imprint", that represent certain "fragments" and have only a "metonymic function". Later, in the works of M. Aranovsky, intertextuality became the dominant characteristic of a musical text. Already in the late 90's of the twentieth century, the stated issue in the aspect of intertextuality was raised in the works of L. Berezovchuk, L. Dyachkova, B. Katz, L. Kazantseva, A. Klimovitsky, I. Kokhanik, V. Moskalenko, I. Pyaskovsky, M. Raku and many others. In particular, various types of intertextuality markers were classified, such as citations, allusions, stylizations, associative images, metaphors, archetypal symbolism, and the like.

In particular, it was noted that it's common practice to use another composer's vocabulary to enhance the musical image, for its gaining a variety of features, which indicates the plasticity of the composer's thinking and characterizes the method of composition itself. At the same time, multilevel units form a single semantic space that has its own logic and is characterized by coherence (connectivity) and goal-oriented communication. Due to this, intertextuality has become the dominant trend in postmodern music art with its associativity, multistylistic thinking, as a kind of model of cognition of reality through the prism of "another's text". It was noted that in texts with a predominant semantic component, there are a number of oppositions such as the sacred - secular, life - death, heaven - earth, and those that have spiritual significance and are oriented to the deeper layers of the human psyche. It was noted that the quotation is an important means of structuring the semantic level of a musical text, which reflects the specifics of the worldview and the nature of the composer's artistic thinking, and the quotation itself in a new context receives a different content, which indicates composer's deep immersion into the style of the original. It was noted that analytical approaches to allusions, as a special type of text implication, allow us to identify various means of expression, from a separate intonation to a metrorhythmic pattern, which can acquire the characteristics of a representative (of a sign) of a certain style. At the same time, attention was focused on the complexity of their analysis, which is influenced by the multilayered nature of the musical text itself, both invariable and variable components.

Further analysis of textual interactions with the aim to identify the semantic levels of musical texts led to the identification of various modes of their comprehension. From such positions, any artistic text, and musical in particular, potentially contains other texts, as a combination of various constructive elements, ideas, plot schemes and structural models, which is conditioned by the peculiarities of artistic thinking, which is based on the baggage of human memory, where artistic signs-images of post-text reality 
are stored. I. e. a musical text is a potential thesaurus of a certain historical and cultural time, and intertextuality is a semiotic space of various language systems that are referentially related to each other.

Results. Despite a large number of thorough studies, it should be noted that the musical discourse is characterized by a pragmatic direction and dialogical character of the texts presented in it, interacting with each other. By "texts" we mean not only the author's intentions in the form of musical compositions, but also performing interpretations, analytical readings (reviews, dialogues, analysis, criticism, and so on) that build the semantics of discourse.

This is a kind of polyphonic form of various musical texts existence, where thoughts "sound", points of view are expressed and semantics of musical culture as a whole are born. In this context, "musical speech" and "music text" are thought of as specific concepts in relation to the generic "discourse" in which they function. It is from such positions that the musical culture of the second half of the XX - beginning of the XXI century is analyzed; in the context of which there were cardinal changes in the understanding of the musical matter itself. As a result, an open form in aleatoric appears, minimalist patterns replace the classical vocabulary, the merging of timbre and texture leads to new principles of compositional organization, the rejection of the classicism causality entails the appearance of not only a new syntax with a super-complex semantics, but also leads to significant changes in musical speech as a whole. Also, analytical vector of semantics of the musical language shifts in the conceptual dimension of musical and speech processes of sense formation as a reflection of the artistic Existence.

To substantiate the voiced opinion we suggest analyzing one of the works of the famous Kharkiv composer V. Ptushkin from the point of view of its existence in the context of the modern musical discourse. In V. Ptushkin's work, various arrangements of his works occupy a large place, so that they acquire new forms of their existence in the context of musical discourse. One of such striking examples that started its own concert life is the Suite in 6 parts "Gulliver" ("Overture", "Lilliputians", "Gavotte", "Paths-roads", "Romance laputyan" and "Tournament of court tightrope walkers") as music from the musical "Huge baby Gulliver" (directed by G. Nikonenko, 2007). Such an approach of the composer to the popularization of his works is conditioned by many years of work in the theatre, which simultaneously exists in many variants and is constantly in the lens of stereoscopic analysis of society.

Socio-cultural realities dictate new forms of mastering the stage, encrusting each time new forms of presenting musical material that is not peculiar to it, while entertainment enters a new media reality, significantly transforming the system of values of public consciousness. V. Ptushkin knew theatrical life with its atmosphere and conditions of existence in the market of commercial services very well. He constantly sought new forms and genres of presenting 
musical material to the audience, realizing that the theatrical product is characterized by multilayering and belongs to the category of "non-speech" services. That is why in his creative arsenal we find various genre forms, including "album in the album" ("On the pages of" Children's album"), the genre of musical installations that occupy their niche in the development of artistic space.

"The Gulliver" suite was performed on many stages and, in particular, in the context of the art project "The Theater of Musical Installations", which took place on October 31, 2014, on the stage of the Mykolaiv Academic Russian Drama Theater, having received a resonance in the artistic life of the city. Innovative forms of presentation of musical material, an organic combination of different types of art in the genre of musical installations allowed to open new genre formats for the implementation of the composer's musical works. In general, the installation as a genre has recently been developed along with such artistic projects as performance, happening, land art, and environment, which represent an extended context for the projection of the artist's semantic gesture. Taking into account all the conditionality of classification and numerous hybrid forms of existence, the installation is divided into three main types, where the first is characterized by a dominant plot-narrative beginning, the second - object-subject, and the third - visual, which emphasizes the contemplation of a certain image. The feature of the installations genre is its objective reality because the action itself takes place in three-dimensional space. Also, this genre feature has its roots in the art of surrealism and, in particular, the work of the author of installations M. Duchamp and his followers: I. Beuys, G. Rauschenberg, D. Kossuth, E. Kinholz, I. Kabakov, and others.

The peculiarity of installations as one of the types of performative genres is its short duration, fragility, fixed only in their subsequent reconstruction. Perhaps that is why their pathos is not in originality, but in magical suggestibility, which is perceived by the audience as a reality in which a demarcation shift occurs, the border between life and art is destroyed. In this surreal space, the magic of understanding of the meaning of the action happens, what feels like "true life" and at the same time as its figurative reproduction when you include all the mechanisms of perception of the artistic whole, from the imagination to the emotional experience and reflection. The perception of artistic reality becomes deeper in the process of perception when one is immersed in the sphere of experience, where the perception of an artistic image and the acquisition of aesthetic experience occur on the border of the real and the subconscious. At the same time, the listener perceives the artistic image in all its complexity and volume as real, objectively existing, and strives to comprehend its semantics. In this context, the pragmatic aspect of its functioning is important, because only in 
co-creation with the listener is the game context of mastering this kind of artistic practice realized. The language of installations is dialogic and, following the idea of I. Gelderlin, is "The house of being", which is given to us in living speech, because "we are the speech". In this sense, the installation is a kind of game in the realm of speech, where pauses sound, where verbal and non-verbal level coexist, which allow shifting the focus from the "process of perception" to a "process of participation", where the boundary of contemplation, and the place of "objectivity" is a dialogue (M. Bakhtin) of different consciousnesses. It was in the context of this experimental genre of installations that the Ptushkin's Suite "Gulliver" was presented, in the multilayered score of which different types of art interacted. The most important in this art action was the process of co-creation, in which the performer and the listener became co-creators of a semantic space, where a special structuring of time formed a "second reality" that existed in the interconnection of many components. In this dialogue, in addition to the music that the author performed with the respondent, plastic (choreographic sketches behind the screen that formed the shadow theater), poetic (the theater's cast), and visual images were involved, which made Gulliver's extraordinary adventures a fairy-tale action. The installation acquired dialogic forms, became a field of exchange of different thoughts, forming a special semantic space.

\section{CONCLUSIONS}

The musical discourse reflects a complex context of relations, which implies a special algorithm for understanding it as an artistic practice that exists in the context of a particular society and includes not only the contextual dimension of its existence, but also the goal, attitudes, and experience of the creator as well as the listener. I. e. musical discourse is a semiotic system in the context of which there is a generation (origination) translation (execution, interpretation, reading) - assimilation (perception) of musical values, where the interaction of all components determines the actualization of its meaning.

The components of musical discourse are heterogeneous by their significance, but they play an important role in the process of musical communication, directing the polylogue vector to the assimilation of musical values.

In musical discourse, the semantic unity of various components of the musical-speech flow, immersed in the situation of musical communication, is manifested. From this point of view, the socio-cultural aspect of musical discourse can be understood due to different forms of its functioning, while the cognitive aspect will reveal the semantic levels of the musical text, its volume, multidimensional character and textual heterogenity. From such positions, the relations of realization are built between the musical text and 
the discourse, where different discourses can manifest themselves in the musical text. It is in the context of musical discourse that thought processes find their explicit expression, acquiring the form of a text characterized by its inclusion in the social context, where speech - text - discourse exist in the space of a macrodialog and is a kind of polyphony of "different voices" of culture.

\section{SUMMARY}

The article deals with the issue of musical discourse which is deemed as a multidimensional text space; taking into account modern trends in the development of linguistics and musicology, the concept of "musical discourse" is analyzed. The article identifies the essential characteristics of musical discourse from the perspective of modern semiosis. The article analyzes the concept of "discourse" from the perspective of modern linguistics and musicology.

It is emphasized that the term "discourse" has deep roots and a variable etymology that has changed over a long time and has had a vector of interpretation from "analytical actions" to "the mechanism of language actualization" in the communication system. It is noted that according to humanitarian approach, under the influence of linguistic studies, various theories of discourse arose, in particular: critical discourse analysis (T. A. van Dyck, N. Ferklow, G. Vodak), structural analysis of myths and the study of communication methods in various cultures (V. Labov, N. Ris), cognitive models of understanding a coherent text and discourse (T. A. van Dyck, D. Kinch), etc. It is emphasized that since the $1960 \mathrm{~s}$, the term "discourse" acquires a categorical meaning and correlates with the concept of "text" which was facilitated by the development of semiotics as a specialized field of knowledge. However, since the $1970 \mathrm{~s}$, the term "discourse" has been specified in scientific researches. It has been interpreted as a way to actualize the text where text and speech were thought of as aspects of discourse. It is emphasized that in theoretical musicology, despite the lack of methodological justification, the term discourse still received its thorough understanding in a number of analytical works, in particular: N. Aranovsky, B. Gasparov, L. Berezovchuk, L. Dyachkova, B. Kats, L. Kazantseva, A. Klymovitsky, I. Kokhanik, V. Moskalenko, I. Pyaskovsky, M. Raku and many others.

Following the stated analytical approach in the context of this article, an attempt is made to identify the content characteristics of musical discourse, which is conceived as a multidimensional text space. It's noted that musical discourse is pragmatically oriented and the texts it comprises are dialogical in nature. By "texts" we mean not only the author's intentions in the form of musical works, but also performing interpretations, analytical readings (reviews, dialogues, analysis, criticism, and so on) that build the semantic 
dimension of discourse. This is a kind of polyphonic form of existence of different musical texts where opinions and points of view are expressed, and semantic dimensions of musical culture as a whole emerge.

It is noted that musical discourse reflects a complex relationships context which implies a special algorithm for understanding it as an artistic practice that exists in the context of a particular society and includes not only the contextual dimension of its existence, but also the goal, attitudes, and experience of the individual as the creator and the listener. I.e., musical discourse is a semiotic system in the context of which there is a generation (procreation) - translation (execution, interpretation, reading) - assimilation (perception) of musical values, where the interaction of all components determines the actualization of its meaning. The components of musical discourse are heterogeneous in their significance, but they play an important role in the process of musical communication, directing the polylogue vector to the assimilation of musical values. The semantic unity of various components of the musical-speech flow, immersed in the situation of musical communication, is manifested in musical discourse. From these positions, the relations of realization are built between the musical text and the discourse, where different discourses can manifest themselves in the musical text. I.e., it is in the context of musical discourse that thought processes find their explicit expression, acquiring the form of a text characterized by its inclusion in the social context, where speech - text - discourse exist in the space of a macro dialogue and is a kind of polyphony of "different voices" of culture.

\section{REFERENCES}

1. Арановский М. Музыкальный текст. Структура и свойства. Москва : Музыка, 1998.

2. Бахтин М. Проблемы содержания, материала и формы в словесном творчестве. Bопросы литературы и эстетики. Москва : Худож. лит., 1975.

3. Берегова О. Сучасні теорії дискурсу і рефлексії в розробці теорії музичної комунікації. Актуальні проблеми мистецької практики $i$ мистецтвознавчої науки. Мистецькі обрії 2 (11). (2009): 185-191.

4. Будагов Р. Введение в науку о языке. Москва : Просвещение, 1965.

5. Водак Р. Язык. Дискурс. Политика / пер. с англ. и нем. Волгоград : Перемена, 1997.

6. Джонсон-Лэрд Ф. Процедурная семантика и психология значения. Новое в зарубежной лингвистике. Когнитивные аспекты языка. Москва : Прогресс, 1988. (23): 234-255

7. Дьячкова Л. Проблемы интертекста в художественной системе музыкального произведения. Интерпретащия музыкального 
произведения в контексте культуры: сб. тр. РАМ им. Гнесиных. Москва, 1996. (129): 17.

8. Карасик В.О категориях дискурса. Языковая личность: соииолингвистические и эмотивные аспекты : сб. науч. тр. Волгоград ; Саратов : Перемена, 1998: 185-197.

9. Кац Б. Об интертекстуальности последней симфонической темы Брамса. Выбор и сочетание: открытая форма: сб. ст. $к$ 75-летию Ю.Г. Кона. Петрозаводск ; Санкт-Петербург, 1995: 18-21.

10. Клименюк А. Знание, познание, когниция : [монография]. Тернополь : Підручники і посібники, 2010.

11. Климовицкий А. «Пиковая дама» Чайковского: культурная память и культурные предчувствия. Россия - Европа: контакты музыкальных культур: сб. научн. трудов Рос. института истории искусств. Проблемьл музыкознания. Санкт-Петербург, 1994 (7): 221-274.

12. Кубрякова Е. Виды пространства текста и дискурса. Пространство и время: материалы научн. конф. Москва : МГУ, 1997.

13. Миронова Н. Оценочный дискурс: проблемы семантического анализа. Известия АН Сер. Литература и язык. 1977. Т. 56. (4): 52-59.

14. Потапчук М. Песенный дискурс как коммуникативный процесс. Вестник Челябинского государственного ун-та. Филология; Искусствоведение 2013: 2 (293): 140-143.

15. Раку М. «Пиковая дама» братьев Чайковских: опыт интертекстуального анализа. Музыкальная академия, 1999 (2): 9-21.

16. Ревзина О. О понятии коннотации. Языковая система и ее развитие во времени и пространстве: сб. научн. статей. Москва : Изд-во МГУ, 2001: 436-446.

17. Степанов Ю. Альтернативный мир, дискурс, факт и принцип причинности. Язык и наука 20 века: сборник статей. Москва : Российский государственный гуманитарный ун-т, 1995.

18. Agawu K. Music as discourse: Semiotic adventures in romantic music. Oxford; New York: Oxford University Press, 2009. 345 p. [in New York, USA].

19. Hoffmann L. Kommunikationsmittel Fachsprache: Eine Einführung. 3. Aufl. Berlin : Sammlung Akademie-Verlag Sprache 44, 1987.

Information about author: Piatnitska-Pozdnyakova I. S., $\mathrm{PhD}$ in Arts, Associate Professor at the Department of Musical Art Mykolaiv V. O. Sukhomlynskyi National University 24, Nikolska str., Mykolaiv, 54030, Ukraine 